„Analecta Cracoviensia” 50 (2018), s. 11-22

DOI: http://dx.doi.org/10.15633/acr.3281

Fr. Szymon Drzyżdżyk

The Pontifical University of John Paul II in Krakow

\title{
Homerocentos and the Ontology of Christ
}

Homerocentons are poetic pieces from the $4^{\text {th }}$ and $5^{\text {th }}$ centuries written in Greek, which attempt to present the Gospel in the language of Homer. Similar to the Homeric poems, they were written with dactylic hexameter, and constructed in such a way that the individual verses of the various books of the Iliad and Odyssey were so connected that their contents corresponded to the Gospel. They emerged in the epoch of heated Christological disputes, and even now it is worth taking a closer look at them to investigate to what extent they record the discussions of the fourth and fifth centuries regarding the identity of Jesus Christ. In the first decade of the $21^{\text {st }}$ century, Rocco Schembra issued five critical manuscripts of the Homerocentos. ${ }^{1}$ Recently the first detailed commentaries ${ }^{2}$ on these works have been produced as well as several significant monographs devoted to their analysis both from the linguistic perspective and from the theological point of view. ${ }^{3}$ The relatively short time since the release of this critic of the Homerocentos reveals a number of issues that are worth investigating. One of these is the ontology of Jesus Christ. This topic is important because it is connected with the issue of the Hellenization of Christianity, which is still being discussed. It is worth analyzing these works from the perspective of the ontology of Jesus Christ. The analysis of all five manuscripts would certainly

1 Homerocentones, ed. R. Schembra, Turnhout 2007.

2 R. Schembra, La prima redazione dei centoni omerici. Traduzione e commento, Alessandria 2006; R. Schembra, La seconda redazione dei centoni omerici. Traduzione e commento, Alessandria 2007.

M. D. Usher, Homeric Stichings. The Homeric Centos of the Empress Eudocia, New YorkOxford 1998; K. O. Sandnes, The Gospel "According to Homer and Virgil". Cento and Canon, LeidenBoston 2011; D. Piasecki, Centony Homeryckie. Spotkanie tradycji pogańskiej z chrześcijańska, Kraków 2014; M. Gilski, Mariologia centonów, Kraków 2015; S. Drzyżdżyk, Chrystologia z perspektywy Mitu Trojańskiego, Kraków 2017. 
exceed the framework of one article, and therefore only one of them, the one containing the most Christological content will be discussed. ${ }^{4}$

The purpose of this article is to answer the question: who is the Jesus Christ presented in the Homerocentos. This issue involves a number of more specific questions: to what extent is the ontology of Jesus Christ depicted on the basis of the Greek terminology contained in the Homeric poems? Whether and to what extent does the category of the God-Man find its counterpart on the pages of the Iliad and the Odyssey? Are the Homerocentos an example of the Hellenization of Christianity? The answer to these questions will be built in three stages: the first step will be to present the Homeric concept of the incarnation of god, the second the biblical, and in the third and last, that which emerges from the pages of Homerocentos.

\section{The Incarnation in Homer}

Many Homeric gods (Aphrodite, Apollo, Athena), not only appear to people, but are actively involved in their lives. For this purpose they assume human form. ${ }^{5}$ They are not bound to one particular person, however, depending on the need, appear in various forms. The goddess Aphrodite takes the form of an old woman, ${ }^{6}$ Apollo as a young man full of power ${ }^{7}$ or as Agenor, ${ }^{8}$ Athena as Laodocus, ${ }^{9}$ prince, ${ }^{10}$ mentor ${ }^{11}$ or herald, ${ }^{12}$ Hermes as a young prince, ${ }^{13}$ Iris

4 Secunda Homerocentonum Conscriptio. Manuscript found in: Homerocentos, ed. R. Schembra, op. cit., p. 155-285. This version of the Homerocentos has the most periscopes. Also, the single verses describing the ontology of Jesus Christ are not found in any other version. See also S. Drzyżdżyk, Chrystologia..., op. cit., p. 20.

5 On the topic of Homeric Epiphanies: P. Pucci, Epifanie testuali nell" "Iliade", "Studi Italiani di filologia classica" 78 (1985), p. 170-183; M. A. Fernandez Contreras, Las epifanías en la épica homérica, "Habis" 30 (1999), p. 7-17.

6 See: Homer, Iliad 3, 385 .

7 See: Homer, Iliad 16, 716.

8 See: Homer, Iliad 21, 596-601; 22, 8-9.

9 See: Homer, Iliad 4, 68-90.

10 See: Homer, Odyssey 13, 223n. The theme of meeting with a young person who is willing to help appears often in the Odyssey. The meeting is usually held on the shore, and the meeting person is the deity who has adopted a human form. See: A. M. Bowie, Homer. Odyssey. Books XIII and XIV, Cambridge 2013, p. 134.

${ }^{11}$ See: Homer, Odyssey 2, 286.

12 See: Homer, Odyssey 8, 12.

${ }_{13}$ See: Homer, Iliad 24, 347-461. 
as Laodiki ${ }^{14}$ and Poseidon as Calchas. ${ }^{15}$ The reasons for these short-lived incarnations are different. Some are meant to reveal important information to the human being, for others the message is meant to encourage or warn him, and others allow the gods to confront people on the battlefield. Often the appearance of gods in the form of birds is seen, such as a hawk ${ }^{16}$ or heron. ${ }^{17}$ In fact, the incarnation of the gods in Homeric poems have a temporary nature, with the goal of bringing about some short-term mission. The appearance of a deity in the form of a child in not found in the Iliad or the Odyssey.

The Homeric epiphanies, however, are not only Docetic. The gods are vulnerable to injury, not only do they feel pain, ${ }^{18}$ but their wounds bleed as well. Diomedes spear hurts both Aphrodite and Ares. The blood is drained from the goddess and the god of war. ${ }^{19}$ Although the gods have wounds from which blood flows, this is not human but divine blood, which is related to the fact as the Homeric poems expressly point out - that divine meals are different from human ones because they neither eat bread nor drink wine. Homer calls it "immortal blood" and specifies it with a special term (ikhor).$^{20}$ In fact, it is not blood, but a special substance that is the equivalent of human blood. It is therefore proposed that the incarnations of the Homeric deities are not only short-lived, but also incomplete. The deity does not become a man even for a moment. In spite of appearing in human form the god is bound by some kind of self-limitation, since in battles with the brave warriors at Troy they sometimes suffer defeat, suffer wounds and are forced to flee from the battlefield.

The Homeric poems emphasize in many ways the enormous gap between the gods and men. The first are called "immortals" (athanatoi), while the latter are "mortals" (thnetoi) ${ }^{21}$ Immortality is synonymous with being a god and mortality with being human. We will not find any character in Homer who will pass from the immortal to the mortal world. ${ }^{22}$ The reverse situation is possible, however, Ganymede, because of his beauty, was kidnapped by the

${ }^{14}$ See: Homer, Iliad 3, 122-124.

15 See: Homer, Iliad 13, 45-62.

16 See: Homer, Iliad 13, 45-62; Odyssey 15, 526.

${ }^{17}$ See: Homer, Iliad 10, 274.

18 G. S. Kirk, The Iliad: A Commentary, vol. 2, Cambridge 1990, p. 97.

19 See: Homer, Iliad 5, 337-340; 5, 857.

${ }^{20}$ See: G. S. Kirk, The Iliad..., op. cit., p. 97.

${ }^{21}$ See: R. Janko, The Iliad: A Commentary, vol. 4, Cambridge 1992, p. 180, 376.

${ }^{22}$ The idea of descent into the earth and ascending into heaven is known in both Hellenistic and Judaic literature, and then Christian, but descent does not mean becoming totally human. See: 
gods, becoming the cupbearer of Zeus, and thus he entered permanently into the world of immortality. ${ }^{23}$ So there is the possibility of crossing the divide between the gods and humans. This is possible in only one direction: the mortal can be accepted by the grace of the gods to be immortal.

\section{The Biblical Perspective of the Incarnation}

In the Bible the Old Testament highlights in various ways the divide between God and man. Even though God sometimes forms covenants with the people, though he leads his people out of the captivity of Egypt, though he guides them through the wilderness by day as a cloud and by night as fire, though he lives among his people first in the Tent of Meeting and then in the Temple of Jerusalem, though he treats his nation in a unique way, describing it as a "bride," ${ }^{24}$ no man can see him because it would mean death for him. ${ }^{25}$ God communicates with his people primarily through prophets and angels.

The New Testament shows God who became man. The Word became flesh, ${ }^{26}$ thus bridging the gap between the world of the divine and the world of the human. In contrast to the Greek mythology contained on the pages of the Iliad and the Odyssey, the incarnation of the Son of God is not short-lived, but it covers a period of more than thirty years of earthly life, and as interpreted by the Council of Chalcedon continues, because the Logos forever became a man, since in Christ there is no the possibility of disconnection or separation of the natures. ${ }^{27}$ The New Testament presents the incarnation as encompassing the various stages of human life: from conception, through birth, adolescence, maturity, to death, resurrection, and ascension. It shows the death of Jesus as something extremely real, it emphasizes the fact that the Immortal in reality, not in appearance, became a mortal. ${ }^{28}$ While Homer's poems emphasized the possibility of moving from the mortal world to the immortal world, the New

Ch. H. Talbert, The Development of Christology during the First Hundred Years and Other Esseys on early Christian Christology, Leiden-Boston 2011, p. 83-111.

${ }^{23}$ See: Homer, Iliad 20, 233-235. See also: M. W. Edwards, The Iliad: A Commentary, vol. 5, Cambridge 1991, p. 319-320.

${ }^{24}$ See: T. D. Łukaszuk, Ty jesteś Chrystus, Syn Boga żywego. Dogmat chrystologiczny w ujęciu integralnym, Kraków 2000, p. 52-58.

25 See: Ex 33:20.

${ }^{26}$ See: Jn 1:14.

27 See: T. D. Łukaszuk, Ty jesteś Chrystus..., op. cit., p. 273-274.

${ }^{28}$ See: W. Kasper, Jezus Chrystus, Warszawa 1983, p. 112-122. 
Testament witnessed the opposite. This realism of the incarnation is also expressed in the suffering of Jesus and in the shedding of His fully human blood.

\section{The Incarnation in the Homerocentos}

The Homerocentos try to combine the biblical perspective with the mythical perspective of Homer. However, these works make little reference to the Old Testament, referring only to Original Sin and its consequences, focusing primarily on the content contained in the New Testament - the life of Jesus from conception until his ascension - and thus constitute an attempt to harmonize the Hellenistic and Christian conception of incarnation.

From the point of view of Jesus' ontology, the texts that expressis verbis evoke the notions of nous and thymos in regard to Jesus, because they describe his "interior," and the formulations that define him as God-man. Among the biblical pericopes, in which the writer of the cento indirectly but clearly presents his view of the incarnation of the Son of God, in the foreground stand out: the pre-existence of the Son of God, Jesus' temptation in the desert, his prayer at Gethsemane and his ascension. In these texts, the author of the centos made some modifications - omissions or additions - that shed some light on the ontology of Christ.

\subsection{The nous and thymos of Jesus Christ}

Both the term nous and the term thymos in various meanings occur in the Homerocentos many times. According to the Iliad, it is Zeus who gives nous to the people so that they won't die. ${ }^{29}$ Only a few times does the term nous refer to the Son of God. He has the right mind (nous) ${ }^{30}$, has perfect insight into the human interior (nous), ${ }^{31}$ and after the incarnation he kept the same nous as before. ${ }^{32}$ This last statement seems to be the most significant from the point of view of Jesus' ontology. It appears in the annunciation scene as the author of the cento underlined in many ways the similarity of Jesus to man. In order to properly interpret this formulation, it is first worth mentioning its Homeric context. When Odysseus and his companions reached the island of Circe, some of them went on reconnaissance. Because of their carelessness, they were turned into swine by the goddess. This conversion was not complete, however.

\footnotetext{
29 See: Homer, Iliad 13, 727-734.

${ }^{30}$ See: Secunda Homerocentonum Conscriptio, op. cit., v. 77.

${ }^{31}$ See: Secunda Homerocentonum Conscriptio, op. cit., v. 403.

${ }^{32}$ See: Secunda Homerocentonum Conscriptio, op. cit., v. 230.
} 
Although their external appearance and voice had changed, this, as the Odyssey notes, did not change their nous. ${ }^{33}$ They were fully aware of who they were. Changes made in the realm of the flesh do not touch the sphere of identity. Trying to explain the mystery of the Incarnation, the author of the cento does not therefore repeatedly present divine epiphany on the pages of the Iliad and the Odyssey, but instead converts people into pigs. Such a look at the incarnation of the Son of God seems to be the closest analogy in the Apollinaryistic conception of the incarnation in which the Logos replaced the human nous. ${ }^{34}$ The writer of the cento understands the incarnation as a purely external change, showing some analogies of the incarnation of deities in the Homeric poems.

The term thymos appears many times in the Homerocentos. ${ }^{35}$ The many contexts that stand out in terms of reflection on the ontology of Christ are those that emphasize that the spirit that possesses him is the same as before, a very strong spirit. The author of the cento recalls this formula eight times. These words refer to the sleeping Child Jesus, Jesus coming for baptism, performing the miracle at Cana, the resurrection of Jairus' daughter, the quieting of the storm at sea, driving peddlers from the temple, dying on the cross and the resurrection..$^{36}$ Also, this formulation seems to be interpreted in the Apollinarian sense. The incarnation does not therefore mean the kenosis of the Son of God. ${ }^{37}$

\subsection{God-Man}

Although no one in the Homeric poems is simultaneously a god and a human being, the authors of the Homerocentos, as a result of an artificial combination of texts, succeed in presenting Jesus Christ. For this purpose, however, he had to make some adjustments to the Homeric texts. The Homeric poems mention the common action of the gods and people on several occasions. And so the goddess Calypso from her cave gives Odysseus his meal ${ }^{38}$ and Ksantana promises Achilles that he would die at the hands of god and man. ${ }^{39}$ The author of the centos changes the meaning of these formulations in such a way that

33 See: Homer, Odyssey 10, 240; A. Heubeck, S. West, J.B. Hainsworth, A Commentary on Homer's Odyssey, vol. 1, Oxford 1988, p. 57.

${ }^{34}$ See: B. Sesboüé, J. Wolinski, Historia dogmatów, t. 1: Bóg zbawienia, Kraków 1999, p. 315-316.

35 See: M. Gilski, Mariologia..., op. cit., p. 99.

${ }^{36}$ See: Secunda Homerocentonum Conscriptio, op. cit., v. 274, 400, 486, 516, 1058, 1313, 1671, 1867.

37 Problems of translation and interpretation of this text are discussed in: R. Schembra, La seconda..., op. cit., p. 91-92.

${ }^{38}$ See: Homer, Odyssey 5, 194.

39 See: Homer, Iliad 19, 421. 
it is the one person of Jesus Christ, God and Man at the same time. ${ }^{40}$ For this purpose, the plural verbs are changed to the singular to emphasize that it is a single person. The Homeric texts quoted emphasize the two natures of Jesus Christ, divine and human. ${ }^{41}$

Already in the introductory verses of the Homerocentos, the author presents to all men that there is an incentive to know God and man. ${ }^{42}$ In the Iliad, Diomedes receives from the goddess Athena the unique gift of being able to distinguish the difference between god and man on the battlefield. ${ }^{43}$ The author of the cento uses this gift of identifying the combat participant to encourage learning about Jesus Christ, God and Man. Homer sees an opportunity to recognize the identity of god and man only as a result of special divine gift, while the author of the Homercento goes a bit further, pointing out that such knowledge is within reach of countless individuals. ${ }^{44}$

The author of the cento describes Jesus three times as God and man at the same time: In the introduction, he invites all people to know him, then at Lazarus' resurrection, trying to explain in how the dead return to life, and in the context of the Last Supper and the Passion perspective, thus announcing the final victory of the Son of God..$^{45}$

The determination of Jesus as the God-man is the work of the author of the centos. This idea has no counterpart in Homeric poetry. It is a result of some modification in the text that allowed it to give a new, unknown meaning to Homer. From this definition emerges the conviction of the author of centos that in Jesus Christ there is both a human element and a divine element. However, there is no clarification regarding the relationship between them. Due to this ambiguity, it is necessary to look at the next Homerocento texts. However, it is important to note a valid conclusion at this time. This is regarding the absence of the Homeric ideas of god-man in the poems. The presentation of this by the author of the centos is a significant problem in Homer's text. From this context we do not have to deal with the Hellenization of Christianity, only with the full distinctness of recognizing the relationship between gods and humans.

40 See: Secunda Homerocentonum Conscriptio, op. cit., v. 1186 i 1459; R. Schembra, La seconda..., op. cit., p. 62.

${ }^{41}$ See: S. Drzyżdżyk, Chrystologia..., op. cit., p. 215.

${ }^{42}$ See: Secunda Homerocentonum Conscriptio, op. cit., v. 4.

${ }^{43}$ See: Homer, Iliad 5, 128.

44 See: S. Drzyżdżyk, Chrystologia..., op. cit., p. 215.

45 See: S. Drzyżdżyk, Chrystologia..., op. cit., p. 216. 


\subsection{The Modifications of the Authors of the Centos}

Without going into the rationale for which the author of the cento left out some relevant details contained in the New Testament and added new ones (perhaps he could not find the Homeric equivalents to these ideas, perhaps he had some of his own assumptions he wished to present), it is worth looking at some selected aspects of the Homerocentos.

An extensive section devoted to the pre-existence of the Son of God deserves special attention. ${ }^{46}$ The author of the centos devotes considerable space to describing the relationship between the Father and the Son. He emphasizes their unity, ${ }^{47}$ their common will, ${ }^{48}$ immortality, ${ }^{49}$ and likeness. ${ }^{50}$ He puts a clear emphasis on the divinity of the Son of God and His equality with the Father. Such an approach seems to have a clearly Arian connotation. The Homerocentos fit with the polemics of the Arian tradition, deprecating the divinity of the Son of God..$^{51}$

The temptation scene in the desert ${ }^{52}$ to a small extent reflects the biblical message. There is no dialogue between Jesus and the evil spirit, which makes it hard to talk about temptation. ${ }^{53}$ After the initial characterization of the figure of Jesus himself, the author of the centos mentions his presence outside the city in the desert where no trees grow. Jesus is approaching the abundant fruit of the garden, which means the need to confront wild animals. ${ }^{54}$ The theme of the garden seems to implicitly refer to the temptation to change stones into bread. The devil's dedication to the temptation of Jesus is perfectly consistent with the concept of the incarnation emerging from earlier Apollianarian studies. The temptation scene was one of great difficulties for Apollinaris of Laodicea. ${ }^{55}$

In the Homerocento the presentation of the prayer in the garden, ${ }^{56}$ it is also difficult to find the struggle of Jesus in prayer reflected in the Gospels, which

${ }^{46}$ See: Secunda Homerocentonum Conscriptio, op. cit., v. 17-8o.

47 See: Secunda Homerocentonum Conscriptio, op. cit., v. 29.

$4^{8}$ See: Secunda Homerocentonum Conscriptio, op. cit., v. 56.

49 See: Secunda Homerocentonum Conscriptio, op. cit., v. 80.

50 See: Secunda Homerocentonum Conscriptio, op. cit., v. 59.

${ }^{51}$ See: S. Drzyżdżyk, Chrystologia..., op. cit., p. 36.

52 See: Secunda Homerocentonum Conscriptio, op. cit., v. 40o-415.

53 See: S. Drzyżdżyk, Demonologia Homerocentonów, "Bielsko-Żywieckie Studia Teologiczne" 17 (2016), p. 93-94.

54 See: Secunda Homerocentonum Conscriptio, op. cit., v. 414-415.

55 See: B. Sesboüé, Jezus Chrystus Jedyny Pośrednik. Rzecz o odkupieniu i zbawieniu, t. 1, Poznań 2015, p. 261. Por. także: S. Drzyżdżyk, Chrystologia..., op. cit., p. 65-67.

${ }_{56}$ See: Secunda Homerocentonum Conscriptio, op. cit., v. 1509-1534. 
results in sweat and blood. His prayer is lamentable and resembles the Old Testament psalms. ${ }^{57}$ Jesus calls to the Father to save him. He agrees, however, with whatever the will of the Father ${ }^{58}$ will be, that is, death and noble glory. The author of the cento concludes this pericope by saying that God Himself had to admire these words. ${ }^{59}$ It is difficult to develop a precise interpretation of this pericope as there is no inner struggle in this scene, which seems to imply that there is no need to harmonize the human will with the divine will. Consequently this thinking close to monothelitism, which seems to be the heir of Apollinarian thought.

In the description of the ascension of Jesus the author of the cento gives significant detail that strongly suggests the dominance of the divine element in Christ. Jesus goes to a high mountain and both his mother and dearest ones accompany him. There he ascends to the clouds of heaven and the Father's house. ${ }^{60}$ The ascension is recognized by the angels guarding the gates of heaven. This detail seems to be very important. The angels recognize God in Jesus Christ. His divinity is not hidden for them. Patristic angelology often stressed the need for a dialogue between the angels of heaven who did not recognize the Word made flesh and the angels of earth who reveal His identity to them. ${ }^{61}$ Jesus then sits on the throne. At this point the author of the cento allows himself another addition, stating that Jesus was the one who saw him for the first time. He was like God the Father in shape and appearance. He then sat in glory at His right hand. He was entrusted with all of heaven. ${ }^{62}$ The author of the cento stresses the similarities of Jesus to the Father so strongly that the important theological dimension of the ascension, which is the elevation of human nature, is lost. The emphasis is primarily on the return of the Son of God to the Father. The absence of any mention of his human nature suggests that we are dealing here with the elements of monophysite thinking, which is the heir of Apollinarism. ${ }^{63}$

${ }^{57}$ K. O. Sandnes, Early Christian Discourses on Jesus' Prayer at Gethsemane. Courageous, Committed, Cowardly?, Leiden 2016, p. 301.

${ }^{58}$ See: Secunda Homerocentonum Conscriptio, op. cit., v. 133-136.

59 See: Secunda Homerocentonum Conscriptio, op. cit., v. 1524-1534.

${ }^{60}$ The idea of return is the main theme of the Odyssey. See: K. O. Sandnes, The Gospel..., op. cit., p. 222-228.

${ }^{61}$ See: J. Daniélou, Aniołowie i ich misja, Warszawa-Ząbki 2006, p. 65n.

${ }^{62}$ See: Secunda Homerocentonum Conscriptio, op. cit., v. 1907-1924.

${ }^{63}$ See: S. Drzyżdżyk, Chrystologia..., op. cit., p. 150. 


\section{Summary: The Analysis of the Homerocentos from the Viewpoint of Jesus Ontology Allows us to Formulate the Following Conclusions}

The author of the centos in many ways highlights the divinity of Jesus Christ, devoting a lot of space to reflection on the pre-existence of the Son of God, showing him as equal with the Father, emphasizing the unanimity of the Father with the Son, the unity of the will, immortality, and their mutual likeness. The Homerocentos have a distinctly anti-Arian character. Thorough analysis makes it possible to see their anti-subordinationist and antimodal dimension. The Son of God is a person separate from the Father and equal to Him.

Analysis of the Homerocentos reveals their anti-docetic dimension. Jesus really suffers and, in contrast to the Homeric gods, has real human blood and really dies. The possession of human blood and becoming mortal is the absolute novum Homerocento in relation to the Homeric poems. These components do not allow one to see the Homerocento example of Hellenized Christianity, but rather to emphasize the otherness of the Gospel contained in the transmission.

It can be concluded from these works that the concept of the incarnation which emerges from the Homerocentos record an Apollinarian concept of the incarnation, in which the divine Logos replaced the human nous. Apollinaris of Laodicea was the author of numerous hexametrical pieces known in antiquity, so it is not surprising that the authors of the centos have preserved his understanding of the incarnation. The idea of a God-Man is absent in the Homeric poems. The author of the centos was not able to present this based on the text of the Iliad and the Odyssey. It appeared only to a certain extent due to the adjustments made to Homer's poems.

\section{Abstract}

This article deals with the problem of the ontology of Jesus Christ that emerges from the pages of the poetic works of the fourth and fifth century that are known as Homerocentos. It consists of three parts. The first presents the Homeric concept of the incarnation, which shows the understanding of the incarnation of the deity present in the Iliad and the Odyssey. In the second, a brief approximation of the incarnation tendency present in the Bible. The final part focuses on an attempt to harmonize the biblical and Homeric conception of the incarnation, and thus to reveal the ontology of Jesus Christ in the Homerocentos. 


\section{KEYWORDS}

Apollinariansim, Hellinization, Homerocentos, ontology of Jesus Christ

\section{ABSTRAKT}

\section{Homerocentony a ontologia Chrystusa}

Artykuł podejmuje problem ontologii Jezusa Chrystusa wyłaniającej się z kart poetyckich utworów z IV i v wieku, określanych mianem Homerocentonów. Składa się z trzech części. Pierwsza prezentuje homerycką koncepcję wcielenia, ukazując rozumienie wcielenia bóstwa obecne w Iliadzie i w Odysei. W drugiej zostaje krótko przybliżona tendencja inkarnacyjna obecna w Biblii. Ostatnia część koncentruje się na próbie zharmonizowania biblijnej i homeryckiej koncepcji wcielenia, a zatem na ukazaniu ontologii Jezusa Chrystusa w Homerocentonach.

\section{SEOWA KLUCZOWE}

apolinaryzm, hellenizacja, Homerocentony, ontologia Jezusa Chrystusa

\section{BIBLIOGRAPHY}

Daniélou J., Aniołowie i ich misja, Warszawa-Ząbki 2006.

Drzyżdżyk S., Chrystologia z perspektywy Mitu Trojańskiego, Kraków 2017.

Drzyżdżyk S., Demonologia Homerocentonów, „Bielsko-Żywieckie Studia Teologiczne” 17 (2016), p. 89-98.

Edwards M. W., The Iliad: A Commentary, vol. 5, Cambridge 1991.

Fernandez Contreras M. A., Las epifanías en la épica homérica, „Habis” 30 (1999), p. 7-17.

Gilski M., Mariologia centonów, Kraków 2015.

Heubeck A., West S., Hainsworth J. B., A Commentary on Homer's Odyssey, vol. 1, Oxford 1988.

Homer, Ilias, Rhapsodias 1-12 continens, rec., testimonia congessit M. L. West, Stuttgart 1998.

Homer, Ilias, Rhapsodias 13-24 et indicem nominum continens, rec., testimonia congessit M. L. West, München 2000.

Homer, Odyssea, rec. A. Ludwich, vol. 1, Editio stereotypa editionis primae (1889), Stutgardiae et Lipsiae 1998.

Homer, Odyssea, rec. A. Ludwich, vol. 2, Editio stereotypa editionis primae (1889), Stutgardiae et Lipsiae 1998.

Homer, Odyssey. Books XIII and XIV, ed by A. M. Bowie, Cambridge 2013. 
Homerocentones, ed. R. Schembra, Turnhout 2007.

Janko R., The Iliad: A Commentary, vol. 4, Cambridge 1992.

Kasper W., Jezus Chrystus, Warszawa 1983.

Kirk G. S., The Iliad: A Commentary, vol. 2, Cambridge 1990.

Łukaszuk T. D., Ty jesteś Chrystus, Syn Boga żywego. Dogmat chrystologiczny w ujęciu integralnym, Kraków 2000.

Piasecki D., Centony Homeryckie. Spotkanie tradycji pogańskiej z chrześcijańska, Kraków 2014.

Pucci P., Epifanie testuali nell" "Iliade", "Studi italiani di Filologia classica" 78 (1985), p. $170-183$.

Sandnes K. O., The Gospel "According to Homer and Virgil". Cento and Canon, Leiden-Boston 2011.

Sandnes K. O., Early Christian Discourses on Jesus' Prayer at Gethsemane. Courageous, Committed, Cowardly?, Leiden 2016.

Schembra R., La prima redazione dei centoniomerici. Traduzione e commento, Alessandria 2006.

Schembra R., La seconda redazione dei centoniomerici. Traduzione e commento, Alessandria 2007.

Sesboüé B., Jezus Chrystus Jedyny Pośrednik. Rzecz o odkupieniu i zbawieniu, t. 1, Poznań 2015.

Sesboüé B., Wolinski J., Historia dogmatów, t. 1: Bóg zbawienia, Kraków 1999.

Talbert Ch. H., The Development of Christology during the First Hundred Years and Other Esseys on Early Christian Christology, Leiden-Boston 2011.

Usher M. D., Homeric Stichings. The Homeric Centos of the Empress Eudocia, New York-Oxford 1998. 